Research Article

\title{
Growth medium screening for chlorella vulgaris growth and lipid productions
}

\begin{abstract}
To overcome the variation of lipid productivity of $C$. vulgaris, the objective of the present research was to investigate the effect of various growth medium compositions on Chlorella vulgaris (C. vulgaris) in an attempt to enhance its growth and lipid production using batch culture conditions. Thirteen different growth media were being tested in culture tubes in stage 1. Maximum optical density reading was recorded for the bold basal medium $\left(\mathrm{OD}_{683}\right.$ : $3.389 \pm 0.023)$. Besides, in the large scale experiment, Bold basal medium was observed the highest biomass productivity $\left(114.208 \pm 0.850 \mathrm{mg} \mathrm{L}^{-1}\right.$ day $\left.^{-1}\right)$ in day 12 and specific growth rate $\left(\mathrm{d}^{-1}\right)(0.279 \pm 0.001)$. Highest lipid content $(17.640 \pm 0.002 \%$, day 12$)$, lipid productivity $(250.576 \pm 4.834 \mathrm{mg} / \mathrm{L}$, day 12$)$ and overall lipid productivity of $20.881 \pm 0.403 \mathrm{mg} \mathrm{L}^{-1}$ day ${ }^{1}$ was also achieved the highest in Bold basal medium, by comparing with other selected medium. Further study is required with a focus on one or two particular nutrients (with alteration in concentration) in one type of medium, and other factors remaining unchanged each time to find out the induce effect of nutrients to the biomass and lipid accumulation.
\end{abstract}

Keywords: Chlorella vulgaris, Growth medium, Screening, Algal cultivation, Biomass production, Lipid production
Volume 6 Issue I - 2017

\author{
YK Wong, ${ }^{1,2}$ YH Ho, ${ }^{2} \mathrm{KC} \mathrm{Ho},{ }^{2} \mathrm{HM}$ Leung, \\ KKL Yung' \\ 'Biology Department, The Hong Kong Baptist University, China \\ ${ }^{2}$ Center for Research in Environmental Science, The Open \\ Universityof Hong Kong, China
}

Correspondence: YK Wong, Biology Department, The Hong Kong Baptist University, China, Email yekwong@ouhk.edu.hk

Received: June 28, 2017 | Published: July 14, 2017

\section{Introduction}

Recently, microalgae are common in both industrial and scientific cultivation. There are different fields of application for microalgae includes food, biofuels, fish feed and pharmaceutical products. ${ }^{1}$ Recently, various applications were found for Chlorella vulgaris $(C$. vulgaris) such as a health food, fish feed and nutrition supplements for human consumption, as well as for lipid and biodiesel production. Algae produced its own food by autotrophic nutrition. The food produced is stored as carbohydrates (mainly as starch) and lipid. ${ }^{2,3}$

In developing an optimal process for $C$. vulgaris biomass, two main aspects are usually considered, (1) the external factors such as temperature, light intensity, $\mathrm{pH}$, aeration and agitation, (2) the selection of suitable nutrient. ${ }^{4}$ Nutrient can be the limiting factors in affecting the quality and quantity of the biomass and lipid (FAMEs) in microalgae. ${ }^{5,6}$ Thus, medium screening and optimization is necessary to determine the feasibility for such recipe on the algae cultivation.

Extensive studies have been carried out on investigating the growth and lipid productivity of $C$. vulgaris in growth media., ${ }^{7,8}$ The conclusion as that various additions of nutrients in medium recipe showed a direct effect on the cell content, such as lipid, biomass, carbohydrate, protein, chlorophyll and pigments. ${ }^{9,10}$ Artificial media with known chemical composition is used to stimulate diverse nutrient requirement of the growth for particular algal species. There are a number of media recipes which is commonly used for the microalgae cultivation. ${ }^{11}$ However, the growth media recipes found, may not be adaptable to various kinds of species, such as freshwater and marine-water algae. The composition of growth medium is the most important factors for lipid accumulation for $C$. vulgaris. The deficient of nitrogen in recipe has an important effect on biomass production and lipid production under autotrophic cultivation mode. ${ }^{12}$ The report shows that nitrogen deficient could increase the cell lipid content from $43 \%$ to $53 \%$ of the dry weight of C. vulgaris. ${ }^{13}$

In studying the effect of nutrients towards algal growth, batch cultivation was common as the selected feeding mode. ${ }^{14}$ The batch culture mode consists of a single inoculation algae strain inside the containers, growth under required culture conditions. The harvesting was carried out for certain days, if the algae production reaches its maximum or near-maximum density. ${ }^{15}$ This cultivation technique required limited amount of organic and inorganic nutrients. In order to enhance cost-effective of the lipid production by $C$. vulgaris, research is required on characterizing the nutrient content in the growth medium recipe to cultivate the desire algae species at a high yield and low cost. ${ }^{16}$

\section{Materials and methods}

\section{Microalgae culture}

The microalgae strain used in this study was $C$. vulgaris CCAP 211/11B (Culture Collection of Algae and Protozoa, Argyll, UK). All experiments were performed at a temperature controlled environment at $25 \pm 3{ }^{\circ} \mathrm{C}$. The light was provided by a cool white LED (T5 $15 \mathrm{~W}$ $\left.6400 \mathrm{~K}, 80 \mu \mathrm{mol} \mathrm{m} \mathrm{m}^{-2} \mathrm{~s}^{-1}\right)$ with continuous illumination within the experimental period.

\section{Experimental set-up}

The experiments were separated into two stages and performed with three replicate cultures.

Stage 1: To investigate the effects of different growth media on optical densities (OD) of $C$. vulgaris. $C$. vulgaris was cultured inside the culture tubes with $25 \mathrm{ml}$ of different growth media. The culture tubes were held within a water-bath shaker (Grant - GLS Aqua 18 Plus). To prevent sedimentation of microalgae, the water-bath shaker was shaken at a rate of $150 \mathrm{rpm}$ to provide a shaking movement. $C$. vulgaris was cultured for 12 days and the initial cell concentration was $1.18 \times 108$ cells $/ \mathrm{mL}$.

Stage 2: Subsequently, the effects on biomass and lipid production of $C$. vulgaris Were further investigated in the top five growth media which exhibited the best growth rate in stage 1.C. vulgaris was cultured inside the laboratory conical flask with 2-L growth medium. 
Sterilized air was supplied by an air pump (Hailea V-30), a disposable syringe filter (ADVANTEC DISMIC-250CS, $0.45 \mu \mathrm{m}$ ) and a flexible aquarium air curtain. C. vulgaris was cultured for 12 days and the initial cell concentration was $1.24 \times 10^{8}$ cells $/ \mathrm{mL}$.

\section{Growth medium}

The screening of the growth medium was performed by the thirteen selected growth media: Modified Chu's No. 10, ${ }^{17}$ Bold basal, ${ }^{18}$ BG-11, ${ }^{19}$ Modified BG-11, ${ }^{4} \mathrm{~N}-8, \mathrm{M}-8^{20} \mathrm{RM},{ }^{21}$ Modified Spirulina, ${ }^{22,23}$ $\mathrm{F}-\mathrm{Si},{ }^{24} \mathrm{Fogg}$ 's Nitrogen free, ${ }^{25,26,27} \mathrm{~F} / 2,{ }^{28} \mathrm{Johnnson} .{ }^{29}$ Those were selected for investigation in this study.

\section{Microalgae growth determination}

C. vulgaris growth was determined by measuring the optical density (OD) using OPTIZEN POP (UV/Vis spectrophotometer). For the determination of a suitable wavelength that can $\operatorname{detect} C$. vulgaris, UV absorbance was scanned with the wavelengths ranged from 200 to $800 \mathrm{~nm}$ with difference cell density. ${ }^{30} 683 \mathrm{~nm}$ was the peak absorbance determined and the cell density was measured by this wavelength. The "Phytoplankton Counting Techniques" (American Public Health Association, 1995) 31 $^{31}$ method was used to determine cell count (cells/ ml) using Sedgwick-Rafter counting chambers through a light microscope. Algal biomass samples were filtered using a glass fiber filter (ADVANTEC type GC-50, $47 \mathrm{~mm}$ diameter, $0.45 \mu \mathrm{m}$ ). The dry weight of the algal samples was measured by drying the filter paper at $105^{\circ} \mathrm{C}$ for 24 hours. The initial and final weight of the filter paper was measured by lab analytical balance (AND HR-200). Biomass content was calculated from microalgae dry weight produced per liter $(\mathrm{mg} / \mathrm{L})$.

The specific growth rate $(\mu)$ in the exponential phase was calculated according to (Liang et al., 2013):32

$$
\mu=\operatorname{In}\left(x_{2} / x_{1}\right) /\left(t_{2}-t_{1}\right)
$$

Where $\mathrm{x}_{2}$ and $\mathrm{x}_{1}$ are the optical density $\left(\mathrm{OD}_{683}\right)$ at $\mathrm{t}_{2}$ and $\mathrm{t}_{1}$ respectively.

Biomass productivity (B) was calculated by Liang et al. ${ }^{32}$

$$
B=\left(B_{1}-B_{0}\right) /\left(\mathrm{T}_{1}-T_{0}\right)(2)
$$

where $\mathrm{B}_{0}$ and $\mathrm{B}_{1}$ are the mean dry biomass concentration at the times $\mathrm{T}_{0}$ and $\mathrm{T}_{1}$, respectively.

\section{Nutrient analysis in growth medium}

For nutrient analysis, the sample was filtered through an Advantec glass fiber filter (ADVANTEC type GC-50, $47 \mathrm{~mm}$ diameter, $0.45 \mu \mathrm{m})$ and frozen at $-35^{\circ} \mathrm{C}$ for later analysis. On the day of nutrient analysis, samples were thawed and allowed to reach room temperature. A UV-1800 UV spectrophotometer (Shimadzu) was used to measure the wavelength for nitrate concentration analysis. Nitrate concentration $\left(\mathrm{NO}_{3}^{-}-\mathrm{N}\right)$ was measured using the standard method for Nitrogen - Nitrate, $\mathrm{NO}_{3}^{-}-\mathrm{N}$, the ultraviolet spectrophotometric screening method (American Public Health Association, 1998) ${ }^{33}$ with UV-1800 UV spectrophotometer (Shimadzu) at $220 \mathrm{~nm}$ and $275 \mathrm{~nm}$. A DR/890 portable colorimeter (HACH Company, Colorado, U.S.) and appropriate test kits were used to analyze the nutrient content (ammonia and phosphates). Method 8155 for Nitrogen, Ammonia (0 to $0.5 \mathrm{mg} / \mathrm{L} \mathrm{NH}_{3}-\mathrm{N}$ ) for water, wastewater, and seawater (HACH Company, Colorado, U.S.) and Method 8048 Phosphorus, reactive ( 0 to $0.50 \mathrm{mg} / \mathrm{L} \mathrm{PO}_{4}^{3-}$ ) for water, wastewater and seawater of the DR/890 portable colorimeter procedures manual were followed. The maximum theoretical and expected nitrate, ammonia and phosphate concentration were calculated and the filtered sample was diluted if needed.

\section{Lipid extraction}

Total lipid content was determined using Bligh and Dyer ${ }^{34}$ with modifications. C. vulgaris culture was isolated and freeze dried (Lab conco freez one 4.5). Approximately $0.05 \mathrm{~g}$ of freeze dried algae sample was used for lipid extraction. The lipid extraction using a mixture of $2 \mathrm{ml}$ chloroform and $2 \mathrm{ml}$ methanol (1:1). ${ }^{34} 2 \mathrm{ml}$ of $0.88 \%$ $\mathrm{NaCl}$ was added to the mixture to improve the performance of lipid extraction. The mixture was shaken vigorously and centrifuged at $5000 \mathrm{rpm}$ for 3 minutes. Methanol/water (top phase) and chloroform (bottom phase) were observed. The chloroform layer was further purified sodium sulphate anhydrous powder and collected into the weighted beaker. The organic solvents inside were evaporated by flushing under high purified nitrogen gas. The remaining lipids were weighed. This provided the percentage of lipids in algal dry weight.

Lipid productivity $(\mathrm{mg} / \mathrm{L})$ was calculated using the formula:

Lipid content (\%) x dry biomass $(\mathrm{mg} / \mathrm{L})$

\section{Chlorophyll and carotenoid determination}

To determine chlorophyll a, chlorophyll $\mathrm{b}$ and total carotenoid content in microalgal cells, the spectrophotometric technique was used. An algal sample was extracted with $100 \%$ acetone. The absorbance of light green supernatant was measured at three wavelengths, 661.6( $\left(\mathrm{A}_{661.6}\right), 644.8\left(\mathrm{~A}_{644.8}\right)$ and $470\left(\mathrm{~A}_{470}\right)$, using the UV-1800 UV spectrophotometer (Shimadzu). The chlorophyll and total carotenoid content of the algal sample was calculated using the following formula: ${ }^{35}$

Chlorophyll a $(\mu \mathrm{g} / \mathrm{ml})\left(C_{a}\right)=11.24 \mathrm{~A}_{661.6}-2.04 \mathrm{~A}_{644.8}$ Chlorophyll $b(\mu \mathrm{g} / \mathrm{ml})\left(C_{b}\right)=20.13 \mathrm{~A}_{644.8}-4.19 \mathrm{~A}_{661.6}$ Total chlorophyll $(\mu \mathrm{g} / \mathrm{ml})=$ Chlorophyll $a\left(C_{a}\right)+$ Chlorophyll $b\left(C_{b}\right)$

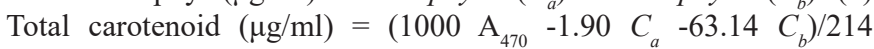
(7)

\section{Statistical analysis}

The data were expressed as means of \pm standard deviation (SD). Statistical analysis was carried out by using SPSS software (Version 21). The optical density, cell numbers and dry biomass concentration were tested statistically using one-way analysis of variance (ANOVA) and post-hoc Turkey's honestly significant difference (HSD) test. The significant level was set at $P<0.05$.

\section{Results and discussion}

Stage 1: Screening of appropriate medium for $C$. vulgaris in thirteen growth media Table 1 shows $C$. vulgaris optical density readings (day 12) and the overall specific growth rate during the twelve days' cultivation. Generally, the range optical density of the batch cultures was 0.101 to 3.389. Highest optical density was recorded in the Bold basal (3.389 \pm 0.023$)$. Followed by M-8 (2.699 \pm 0.043$)$, Modified BG-11 (2.387 \pm 0.017$)$, Modified Spirulina medium (1.948 \pm 0.025$)$ and N-8 medium (1.756 \pm 0.005$)$, respectively. Figure 1 shows the growth curve of seven growth media with a higher ranking in growth performance of C. vulgaris. The Bold basal medium result in a higher optical density reading starting from the seventh day when compared to the other growth medium conditions. Bold basal medium showed the highest ranking in growth performance among the selected growth media and such finding were in line with Ilavarasi et al. ${ }^{36}$ and Wang et al. ${ }^{37}$ 


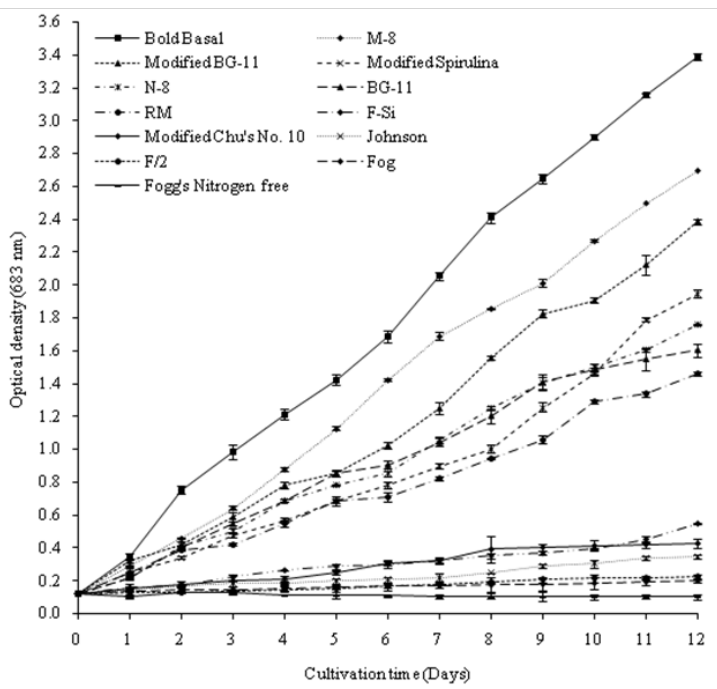

Figure I Optical density reading $(683 \mathrm{~nm})$ in different growth medium in stage I experiment.

Thus, by comparing the nutrient contents in these growth media, addition or deficient of macronutrients (nitrogen, phosphorus and carbon) and micronutrients (magnesium, sulphur and iron) could affect the capability of $C$. vulgaris cultivation. Nitrogenous compounds are important for protein and Chl-a, Chl-b production. ${ }^{38,39}$ When nitrogen is limited, significant decline in the cell division rate and low optical density value was found in the Fogg's Nitrogen free medium. When the cell is starved by limited nitrogen supply, it leads to decrease.

Compare to M-8 and N-8 medium, deficiency of iron and lower amount of magnesium and sulphur content in $\mathrm{N}-8$ medium resulted a lower rate of photosynthesis and growth of $C$. vulgaris. Iron acts as the redox catalyst in photosynthesis and nitrogen assimilation, and participate in the electron transport reactions in photosynthetic organisms. ${ }^{40}$ Magnesium is a constituent of chlorophyll and is essential in the formation of catalase in microalgae. Its deficiency will interrupt the cell division in algae. An addition of a sulphur compound in the M-8 and Modified BG-11 media could promote the growth of $C$. vulgaris by increasing the number of enzymes in the redox and energy produced. ${ }^{41}$ Sulphur is important in the cell division process, protein metabolism and fatty acid synthesis. Sulphur deficiency in growth medium is the stress to cell division and lipid accumulation. ${ }^{41}$ Phosphorus starvation shifted the lipid metabolism from synthesis membrane to neutral lipid storage, which caused the poor growth in $\mathrm{F} / 2$ and $\mathrm{F}$-Si medium. ${ }^{42}$ Compared to the growth performance in thirteen growth media, the negative value of specific growth rate was found in Fogg's Nitrogen free medium (Table 1). F-Si medium recipe does not contain nitrogen and carbon ions. Hence, having a poor growth of C. vulgaris.

Stage 2: Investigation of biomass and lipid productivity of Chlorella vulgaris cultivated in selected media The top five ranking growth media Bold basal, M-8, Modified BG11, Modified Spirulina and N-8were selected for further investigating the biomass growth, lipid productivity of $C$. vulgaris. The statistical analysis showed that the optical density and cell density is significantly different to different growth media culture $(p<0.05)$. Figure 2 shows the optical density measurement $\left(\mathrm{OD}_{683}\right)$ of $C$. vulgaris with five different types of growth media. Generally, the optical density increased from day 0 to 12 .The Bold basal medium had the highest
$\mathrm{OD}_{683}$ reading (3.903 \pm 0.015$)$, followed by $\mathrm{M}-8$ (2.803 \pm 0.019$)$, Modified BG-11 $(2.453 \pm 0.012)$, Modified Spirulina $(2.008 \pm 0.014)$ and $\mathrm{N}-8(1.823 \pm 0.044)$ on day 12 .

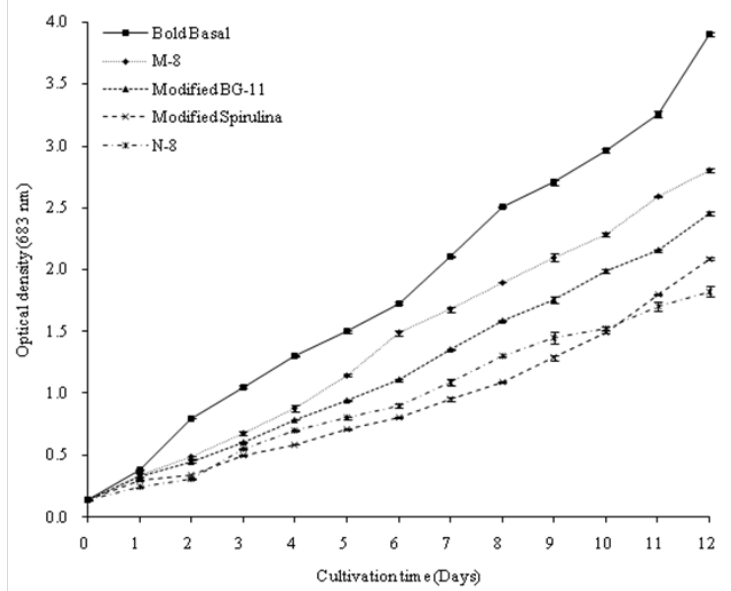

Figure 2 Optical density reading $(683 \mathrm{~nm})$ in different growth medium in stage 2 experiment.

Significant differences were found in the growth of cells starting from the second day of cultivation amongst the growth media (Figure 3 ). Both of the growth medium condition reached a maximum cell concentration at day 12 . Bold basal showed the highest value(3.02 $\times 10^{8} \pm 5.68 \times 10<$ sup $>6</$ sup $>$ cells $/ \mathrm{mL}$ ) after day 12 , followed by M-8 $\left(2.18 \times 10^{8} \pm 3.25 \times 10<\right.$ sup $>6</$ sup $>$ cells $\left./ \mathrm{mL}\right)$, Modified BG-11 $\left(1.88 \times 10^{8} \pm 3.28 \times 10<\sup >6</\right.$ sup $>$ cells $\left./ \mathrm{mL}\right)$, Modified Spirulina medium $\left(1.65 \times 10^{8} \pm 2.52 \times 10<\right.$ sup $>6</$ sup $>$ cells $\left./ \mathrm{mL}\right)$ and N-8 $(1.45$ $\times 10^{8} \pm 5.89 \times 10<\sup >6</$ sup $>$ cells $/ \mathrm{mL}$ ) (Figure 3 ). In all the time, the cell densities in Bold basal media were significantly higher than those in other media.

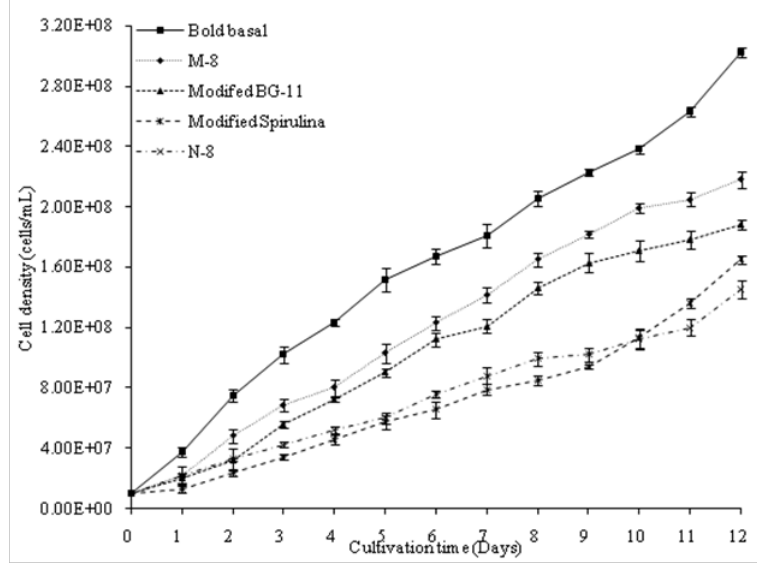

Figure 3 Algae cell density (cells $/ \mathrm{ml}$ ) in different growth medium in stage 2 experiment.

The statistical analysis showed that the biomass dry weight in each media culture are significantly difference to the type of growth media $(p<0.05)$. Figure 4 showed the change in dry mass (as concentration) during the experiment. The descending order of biomass production (day 12) for all five media was Bold basal (mg/L): $1420.500 \pm 10.200$; M-8 (mg/L): $1028.000 \pm 15.000$; Modified BG-11 (mg/L): $900.000 \pm$ 10.000; Modified Spirulina (mg/L): $745.000 \pm 27.820 ; \mathrm{N}-8(\mathrm{mg} / \mathrm{L})$ : $675.500 \pm 22.450$ (Figure 4). Thehighest overall specific growth rate of $0.279 \pm 0.001 \mathrm{~d}^{-1}$ and biomass productivity of $114.208 \pm 0.850 \mathrm{mg}$ $\mathrm{L}^{-1}$ day $^{-1}$ were recorded in the Bold basal medium (Table 2). 


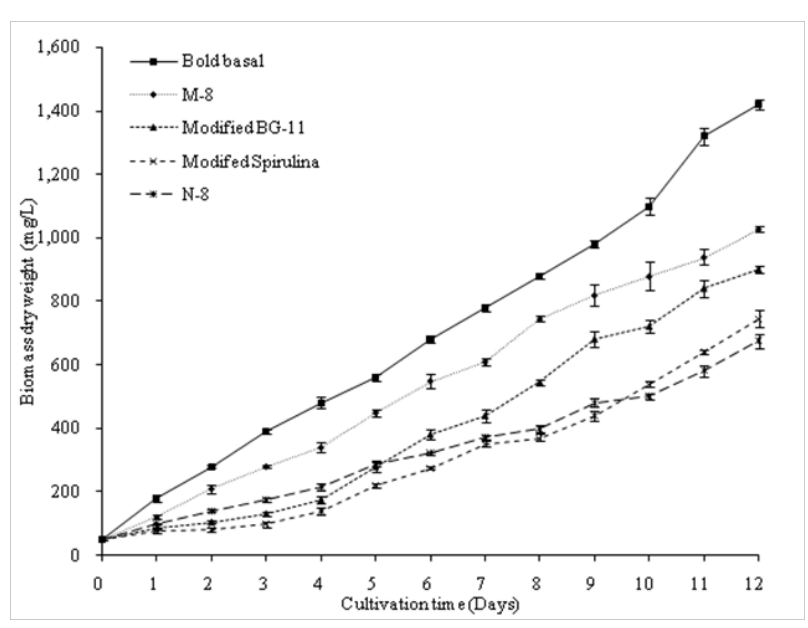

Figure 4 Biomass dry weight in different growth medium in stage 2 Figure 5 Change of Nitrate $\left(\mathrm{NO}_{3}-\mathrm{N}\right)$ concentration in $\mathrm{C}$. vulgaris culture. experiment.

Table I Growth performance, optical density readings and specific growth rate of different growth media in stage I experiment

\begin{tabular}{|c|c|c|c|}
\hline Growth performance (ranking) & Growth medium & $\mathrm{OD}_{683}$ reading (day 12 ) & $\begin{array}{l}\text { Overall specific growth rate } \mu\left(\mathrm{d}^{-1}\right) \\
\text { (as optical density) }\end{array}$ \\
\hline I & Bold basal & $3.389 \pm 0.023^{\mathrm{a}}$ & $0.278 \pm 0.00 l^{a}$ \\
\hline 2 & $M-8$ & $2.699 \pm 0.043^{b}$ & $0.259 \pm 0.00 I^{b}$ \\
\hline 3 & Modified BG-II & $2.387 \pm 0.017^{c}$ & $0.249 \pm 0.00 I^{c}$ \\
\hline 4 & Modified Spirulina & $1.948 \pm 0.025^{d}$ & $0.232 \pm 0.00 I^{d}$ \\
\hline 5 & $\mathrm{~N}-8$ & $1.756 \pm 0.005^{\mathrm{e}}$ & $0.223 \pm 0.000^{\mathrm{e}}$ \\
\hline 6 & BG-II & $1.602 \pm 0.038^{f}$ & $0.215 \pm 0.002^{f}$ \\
\hline 7 & RM & $1.458 \pm 0.013^{8}$ & $0.207 \pm 0.001^{g}$ \\
\hline 8 & $\mathrm{~F}-\mathrm{Si}$ & $0.548 \pm 0.016^{\mathrm{h}}$ & $0.126 \pm 0.00 \mathrm{I}^{\mathrm{h}}$ \\
\hline 9 & Modified Chu's No. 10 & $0.424 \pm 0.027^{i}$ & $0.104 \pm 0.005^{i}$ \\
\hline 10 & Johnson & $0.344 \pm 0.014$ & $0.087 \pm 0.003^{i}$ \\
\hline II & $\mathrm{F} / 2$ & $0.223 \pm 0.006^{k}$ & $0.051 \pm 0.004^{k}$ \\
\hline 12 & Fog & $0.200 \pm 0.008^{k}$ & $0.042 \pm 0.003^{k}$ \\
\hline 13 & Fogg's Nitrogen free & $0.101 \pm 0.005$ & $-0.015 \pm 0.004$ \\
\hline
\end{tabular}

Data are given as mean \pm standard deviation of triplicate experimental culture.

In the column without a common superscript letter is significant differences to each other $(p<0.05)$. As analyzed by one-way ANOVA, Post-Hoc Tests, Turkey HSD.

Table 2 Biomass dry weight (day 12), biomass productivity and overall specific growth rate (based on dry biomass) in different growth medium

\begin{tabular}{|c|c|c|c|}
\hline Growth medium & $\begin{array}{l}\text { Biomass dry weight }(\mathrm{mg} / \mathrm{l}) \\
\text { (day I2) }\end{array}$ & $\begin{array}{l}\text { Biomass productivity } \\
\left(\mathrm{mg} \mathrm{l}^{-1} \text { day-1) }^{-1}\right.\end{array}$ & $\begin{array}{l}\text { Overall specific growth rate }\left(\mathrm{d}^{-1}\right) \\
\text { (as dry biomass) }\end{array}$ \\
\hline Bold basal & $1420.500 \pm 10.200^{a}$ & $1 \mid 4.208 \pm 0.850^{a}$ & $0.279 \pm 0.00 I^{a}$ \\
\hline M-8 & $1028.000 \pm 15.000^{b}$ & $81.500 \pm 1.250^{b}$ & $0.252 \pm 0.00 I^{b}$ \\
\hline Modified BG-II & $900.000 \pm 10.000^{c}$ & $70.833 \pm 0.833^{c}$ & $0.24 I \pm 0.00 I^{c}$ \\
\hline Modified Spirulina & $745.000 \pm 27.820^{d}$ & $57.917 \pm 2.318^{\mathrm{d}}$ & $0.225 \pm 0.003^{d}$ \\
\hline $\mathrm{N}-8$ & $675.500 \pm 22.450^{\mathrm{e}}$ & $52.125 \pm\left. 1.87\right|^{\mathrm{e}}$ & $0.217 \pm 0.003^{\mathrm{e}}$ \\
\hline
\end{tabular}

Data are given as mean \pm standard deviation of triplicate experimental culture.

In the row without a common superscript letter is significant differences to each other $(p<0.05)$. As analyzed by one-way ANOVA, Post-Hoc Tests, Turkey HSD.

Table 3 Nutrient compositions in the algal growth medium used in the stage 2 experiment

\begin{tabular}{|c|c|c|c|c|c|c|}
\hline $\begin{array}{l}\text { Growth } \\
\text { medium }\end{array}$ & Nitrogen compound & $\begin{array}{l}\text { Overall nitrate } \\
\left(\mathrm{NO}_{3}-\mathrm{n}\right)(\mathrm{mg} / \mathrm{l})\end{array}$ & Ammonia compound & $\begin{array}{l}\text { Total ammonia } \\
(\mathrm{mg} / \mathrm{l})\end{array}$ & $\begin{array}{l}\text { Phosphorus } \\
\text { compound }\end{array}$ & Phosphate (mg/l) \\
\hline Bold basal & $\begin{array}{l}\mathrm{NaNO}{ }_{3}^{*} \\
\mathrm{Co}\left(\mathrm{NO}_{3}\right)_{2 \cdot 6 \mathrm{H}_{2}} \mathrm{O}\end{array}$ & 41.24 & $\mathrm{~N} / \mathrm{A}$ & 0 & $\begin{array}{l}\mathrm{K}_{2} \mathrm{HPO}_{4} \\
\mathrm{KH}_{2} \mathrm{PO}_{4} * *\end{array}$ & 163.02 \\
\hline M-8 & $\mathrm{KNO}_{3}$ & 415.62 & $\mathrm{~N} / \mathrm{A}$ & N/A & $\begin{array}{l}\mathrm{K}_{2} \mathrm{HPO}_{4} * * \\
\mathrm{Na}_{2} \mathrm{HPO}_{4} \cdot 2 \mathrm{HO}\end{array}$ & 655.16 \\
\hline Modified BG-II & $\begin{array}{l}\mathrm{NaNO}_{3}^{*} \\
\mathrm{Co}\left(\mathrm{NO}_{3}\right)_{2} \cdot 6 \mathrm{H}_{2} \mathrm{O}\end{array}$ & 247.24 & $\begin{array}{l}\text { Ferric ammonium citrate } \\
\text { (about } 9 \% \text { ammonia) }\end{array}$ & $e_{0.54}$ & $\mathrm{~K}_{2} \mathrm{HPO}_{4}$ & 174.48 \\
\hline \multicolumn{2}{|c|}{ Modified Spirulina $\mathrm{NaNO}_{3}{ }^{*}$} & 411.99 & $\mathrm{~N} / \mathrm{A}$ & N/A & $\mathrm{K}_{2} \mathrm{HPO}_{4}$ & 272.62 \\
\hline $\mathrm{N}-8$ & $\mathrm{KNO}_{3}$ & 138.54 & $\mathrm{~N} / \mathrm{A}$ & N/A & $\begin{array}{l}\mathrm{K}_{2}^{2} \mathrm{HPO}_{4}{ }^{* *}, \\
\mathrm{Na}_{2} \mathrm{HPO}_{4}, 2 \mathrm{HO}\end{array}$ & 655.16 \\
\hline
\end{tabular}

* The major nitrogen source.

** The major phosphorus source. 
Table 4 Total chlorophyll, total carotenoid concentration in Day 0 and I4 in different culture medium

\begin{tabular}{|c|c|c|c|c|}
\hline Growth medium & $\begin{array}{l}\text { Chlorophyll a (mg/l) } \\
\text { (day I 2) }\end{array}$ & $\begin{array}{l}\text { Chlorophyll b (mg/l) } \\
\text { (day I2) }\end{array}$ & $\begin{array}{l}\text { Total carotenoid ( } \mathrm{mg} / \mathrm{l}) \text { (day } \\
\text { I2) }\end{array}$ & $\begin{array}{l}\text { Total carotenoid/ chlorophyl } \\
\text { ratio (day I 2) }\end{array}$ \\
\hline Bold basal & $4.684 \pm 0.023$ & $1.203 \pm 0.083$ & $1.558 \pm 0.037$ & 0.265 \\
\hline M-8 & $3.343 \pm 0.043$ & $0.952 \pm 0.013$ & $0.477 \pm 0.017$ & 0.111 \\
\hline Modified BG-I I & $2.802 \pm 0.058$ & $0.887 \pm 0.045$ & $0.423 \pm 0.028$ & 0.115 \\
\hline Modified Spirulina & $2.334 \pm 0.064$ & $0.765 \pm 0.017$ & $0.384 \pm 0.048$ & 0.124 \\
\hline N-8 & $2.127 \pm 0.019$ & $0.761 \pm 0.028$ & $0.394 \pm 0.045$ & 0.136 \\
\hline
\end{tabular}

Data are given as mean \pm standard deviation of triplicates.

Table 5 Average biomass productivity, lipid content (day 12), lipid productivity (day 12) and overall lipid productivity of Chlorella vulgaris under five different growth media

\begin{tabular}{|c|c|c|c|c|c|}
\hline Medium & $\begin{array}{l}\text { Biomass dry weight } \\
(\mathrm{mg} / \mathrm{l})(\text { day I 2) }\end{array}$ & $\begin{array}{l}\text { Biomass } \\
\text { productivity (mg } \\
\left.\left.\right|^{-1} \text { day }^{-1}\right)\end{array}$ & $\begin{array}{l}\text { Lipid content (\% dry } \\
\text { weight) (day I 2) }\end{array}$ & $\begin{array}{l}\text { Total lipid } \\
\text { productivity }(\mathrm{mg} / \mathrm{l}) \\
(\text { day } \mathrm{I} 2)\end{array}$ & $\begin{array}{l}\text { Overall lipid productivity (mg } \\
\mathrm{I}^{-1} \text { day }^{-1} \text { ) during exp.Time }\end{array}$ \\
\hline Bold basal & $1420.500 \pm 10.200^{\mathrm{a}}$ & $1 \mid 4.208 \pm 0.850^{\mathrm{a}}$ & $17.640 \pm 0.002^{\mathrm{a}}$ & $250.576 \pm 4.834^{a}$ & $20.881 \pm 0.403^{a}$ \\
\hline M-8 & $1028.000 \pm 15.000^{b}$ & $81.500 \pm 1.250^{b}$ & $12.560 \pm 0.003^{b}$ & $129.117 \pm 6.358^{b}$ & $10.760 \pm 0.530^{b}$ \\
\hline Modified BG-II & $900.000 \pm 10.000^{c}$ & $70.833 \pm 0.833^{c}$ & $1 \mathrm{I} .570 \pm 0.002^{\mathrm{c}}$ & $104.130 \pm 4.066^{c}$ & $8.678 \pm 0.339^{c}$ \\
\hline Modified Spirulina & $a 745.000 \pm 27.820^{d}$ & $57.917 \pm 2.318^{d}$ & $11.560 \pm 0.002^{\mathrm{c}}$ & $86.122 \pm 5.833^{d}$ & $7.177 \pm 0.486^{d}$ \\
\hline $\mathrm{N}-8$ & $675.500 \pm 22.450^{\mathrm{e}}$ & $52.125 \pm 1.87 I^{\mathrm{e}}$ & $11.410 \pm 0.001^{\mathrm{c}}$ & $77.075 \pm 5.484^{\mathrm{e}}$ & $6.423 \pm 0.457^{e}$ \\
\hline
\end{tabular}

Data are given as mean \pm standard deviation of triplicate experimental culture.

The findings indicated that a suitable medium for $C$. vulgaris cultivation (for mass or small scale culturing), is the major approach to algae products production (Blair et al., 2013). ${ }^{43}$ Nitrogen is the most important nutrients affecting the biomass growth and lipid accumulation (Griffiths \& Harrison, 2009; Wang et al., 2014). ${ }^{44,37}$ Table 3 shows the concentration of nitrogen and phosphorus source in the five growth media. In our study, only the Bold basal medium showed that nitrate was fully utilized on day 11 of the experiment (Figure 5). All growth media did not show a significant change in orthophosphate $\left(\mathrm{PO}_{4}^{3-}\right)$ concentration, as the recipe contained high amount of phosphorus concentration.

In our study, the highest chlorophyll a, chlorophyll b and total carotenoid concentrations were both observed in Bold basal medium (Chl-a: $4.684 \pm 0.023 \mathrm{mg} / \mathrm{L}$, Chl-b: $1.203 \pm 0.083 \mathrm{mg} / \mathrm{L}$, Total Carotenoid: $1.558 \pm 0.037 \mathrm{mg} / \mathrm{L}$ ) (Table 4). The concentration of chlorophyll and total carotenoid were affected by the dry biomass of the media cultures and the photosynthetic rate. Bold basal medium culture showed the highest growth of algal biomass among the selected growth media. Chlorophyll is the primary pigment in photosynthetic process ${ }^{45}$ Hence, C. vulgaris in Bold basal medium had a higher chlorophyll content.

Carotenoids are the essential components of the photosynthetic tissues in algae, where they participate in the light-harvesting process and protect the photosynthetic apparatus from photo-oxidative damage and oxidative stress. ${ }^{46}$ The relationship between chlorophyll and total carotenoid was calculated by the carotenoid to chlorophyll ratio. Carotenoid to chlorophyll ratio is a sensitive indicator to distinguish the environmental stress and photo oxidative damage in different culture ${ }^{47}$ If the culture exhibits poor growth or is under oxidative stress (for example: illumination or nutrient limitation), carotenoid concentration will increase and result a high carotenoid to chlorophyll ratio. In Bold basal media, the nitrate was fully utilized on day 11 of the experiment (Figure 5). Once nitrogen is starved, it leads to a decrease in the photosynthetic rate. It affected the pigment composition, decrease of Chl-a and Chl-b concentration and increase accumulation of total carotenoid. ${ }^{48}$ Therefore, the highest carotenoid to chlorophyll ratio was observed in Bold basal medium. For lipid yield and lipid productivity, Table 5 shows the change of biomass productivity, lipid content and lipid productivity after the experiment.
The lipid content on day 12 was increased in all cases. The maximum lipid content was obtained in Bold basal was $17.640 \pm 0.002 \%$ (i.e. $7.080 \%$ increased by comparing with an initial \% of lipid content is $10.560 \pm 0.002 \%$. The lowest lipid yield was obtained in N-8 medium, $11.410 \pm 0.001 \%$ with a $0.850 \%$ increase during the culture period (Table 5). Lipid productivity concern the biomass production and lipid content in microalgae. The dry weight and lipid productivity of C. vulgaris on day 12 in different growth media is shown in Figure 6.Comparing the lipid productivity of $C$. vulgaris, the initial lipid productivity on day 0 of $C$. vulgaris was $5.280 \mathrm{mg} / \mathrm{L}$. The highest and lowest overall lipid productivity (day 12) within the culture period was recorded in the Bold basal medium $\left(250.576 \pm 4.834 \mathrm{mg} \mathrm{L}^{-1}\right.$ day $\left.^{-1}\right)$ and $\mathrm{N}-8$ medium $\left(77.075 \pm 5.484 \mathrm{mg} \mathrm{L}^{-1}\right.$ day $\left.^{-1}\right)$, respectively (Table 5).

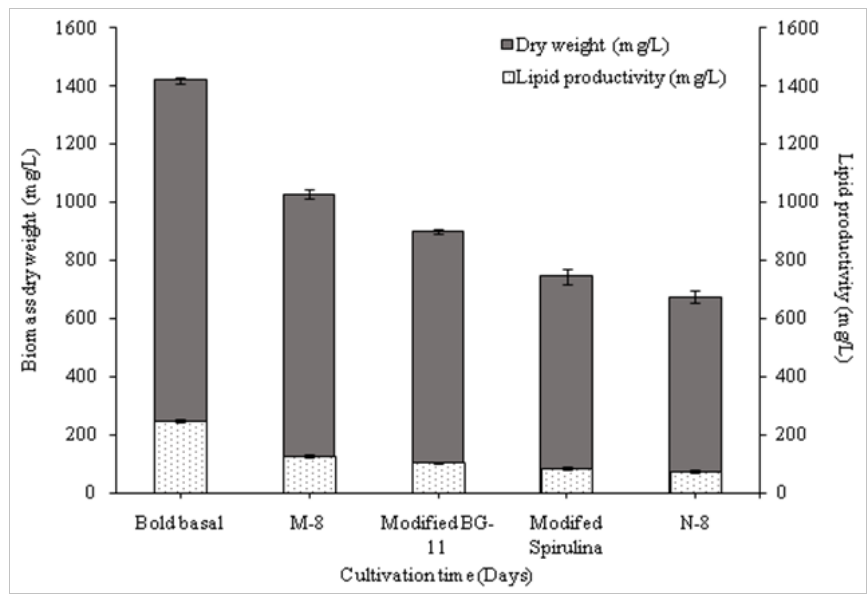

Figure 6 Dry weight and lipid productivity on day 12 cultures of $C$. vulgaris.

In the row without a common superscript letter is significant differences to each other $(p<0.05)$. As analyzed by one-way ANOVA, Post-Hoc Tests, Turkey HSD.

Nitrogen starvation in bold basal medium is the best strategy to induce high lipid content in C. vulgaris cells. Under nitrogen deficiency, algal growth slows down and as there is no requirement for the synthesis of a new cell membrane compounds, in the result, the cells divert and deposit fatty acids into triacyl glycerol (TAG). ${ }^{48,49}$ 
However, within day 12 cultivation, C. vulgaris achieved its highest biomass concentration among the selected media.

On current investigation, $C$. vulgaris in all five media, resulted with a relatively low lipid content. The best reason was medium with excess phosphorus concentration. Phosphorus is important in the production of cellular constituents such as phospholipids, nucleotides and nucleic acids. ${ }^{50}$ Microalgae biomass are generated by the production of ATP and Nicotinamide adenine dinucleotide phosphate (NADPH) in the photosynthetic pathway, while ADP and NADP+ be the acceptor molecules. Excess phosphorus content promotes the growth of microalgae instead of lipid accumulation. If C. vulgaris under phosphorus starvation, will result a lack of ATP synthesis and cause a low or declining biomass growth rate. Phosphorus limitation and starvation are known to induce an increase of triacylglycerol (TAG) (Sharma et al., 2012).$^{48}$ C. vulgaris alter their biomass production pathway towards the formation and accumulation of lipid in their cell bodies, NADP+ become depleted and NADPH is consumed for the fatty acid production to replenish NADP+. ${ }^{48}$

Henceforth, a two-stage culture strategy was recommended (1) the algae is cultured in nutrient-sufficient conditions to obtain a maximized or increased dry biomass as quickly as possible, (2) In pre-harvesting cultural stage (nutrient, nitrogen and phosphorus starvation phase), the growing conditions are modulated to trigger the accumulation of lipids. ${ }^{9}$ However, as the salinity, $\mathrm{pH}$ value of the growth medium and different genotype of $C$. vulgaris, may also bring significant effects of biomass and lipid production. Further study is required with a focus on one or two particular nutrients (with alteration in concentration) in one type of medium, and other factors remaining unchanged each time to find out the induce effect of nutrients to the biomass and lipid accumulation. ${ }^{51}$

\section{Conclusion}

To conclude, Bold basal medium revealed the best specific growth rate $\left(0.279 \pm 0.001 \mathrm{~d}^{-1}\right)$, biomass productivity $(114.208 \pm 0.850 \mathrm{mg}$ $\mathrm{L}^{-1}$ day $^{-1}$ ), lipid yield (Day 12: $17.640 \pm 0.002 \%$ ) and overall lipid productivity $\left(20.881 \pm 0.403 \mathrm{mg} \mathrm{L}^{-1}\right.$ day $\left.^{-1}\right)$. Nitrogen starvation in bold basal medium is the best strategy to induce high lipid content in C. vulgaris cells. A two-stage culture strategy was recommended to obtain a maximize dry biomass first, and later modify the growth conditions to trigger the accumulation of algal lipids.

\section{Acknowledgements}

The work described in this paper was fully supported by a grant from the Research Grants Council of the Hong Kong Special Administrative Region, China (UGC/IDS16/14).

\section{Conflicts of interest}

None.

\section{References}

1. Katarzyna L, Sai G, Singh OA. Non-enclosure methods for non-suspended microalgae cultivation: literature review and research needs. $R e-$ newable and Sustainable Energy Reviews. 2015;42:1418-1427.

2. Choix FJ, de-Bashan LE, Bashan Y. Enhanced accumulation of starch and total carbohydrates in alginate-immobilized Chlorella spp. induced by Azospirillumbrasilense: II. Heterotrophic conditions. Enzyme and microbial technology. 2012;51(5):300-309.

3. Yadala S, Cremaschi S. Design and optimization of artificial cultivation units for algae production. Energy. 2014;78:23-39.
4. Imamoglu E, Sukan FV, Dalay MC. Effect of different culture media and light intensities on growth of Haematococcus pluvialis. Int J Nat Eng Sci. 2007;1(3):5-9.

5. Converti A, Casazza AA, Ortiz EY, et al. Effect of temperature and nitrogen concentration on the growth and lipid content of Nannochloropsisoculata and Chlorella vulgaris for biodiesel production. Chemical Engineering and Processing: Process Intensification. 2009;48(6):1146-1151.

6. Liang Y, Sarkany N, Cui Y. Biomass and lipid productivities of Chlorella vulgaris under autotrophic, heterotrophic and mixotrophic growth conditions. Biotechnology letters. 2009;31(7):1043-1049.

7. Olmstead IL, Hill DR, Dias DA, et al. A quantitative analysis of microalgal lipids for optimization of biodiesel and omega-3 production. Biotechnology and bioengineering. 2013;110(8):2096-2104.

8. Wang L, Min M, Li Y, et al. Cultivation of green algae Chlorella sp. in different wastewaters from municipal wastewater treatment plant. Applied biochemistry and biotechnology. 2010;162(4):1174-1186.

9. Belotti G, Bravi M, de Caprariis B, et al. Effect of Nitrogen and Phosphorus Starvations on Chlorella vulgaris Lipids Productivity and Quality under Different Trophic Regimens for Biodiesel Production. American Journal of Plant Sciences. 2013;4:44-51

10. Vaičiulyte S, Padovani G, Kostkevičienè J, et al. Batch Growth of Chlorella Vulgaris CCALA 896 versus Semi-Continuous Regimen for Enhancing Oil-Rich Biomass Productivity. Energies. 2014;7(6):38403857.

11. Sharma R, Singh GP, Sharma VK. Comparison of different media formulations on growth, morphology and chlorophyll content of green alga, chlorella vulgaris. International Journal of Pharmacy and Biological Sciences. 2011;2(2):B509-B516.

12. Jia Z, Liu Y, Daroch M, et al. Screening, growth medium optimisation and heterotrophic cultivation of microalgae for biodiesel production. Applied biochemistry and biotechnology. 2014;173(7):1667-1679.

13. Mujtaba G, Choi W, Lee CG, et al. Lipid production by Chlorella vulgaris after a shift from nutrient-rich to nitrogen starvation conditions. Bioresource technology. 2012;123:279-283.

14. Zhu L. Microalgal culture strategies for biofuel production: a review. Biofuels, Bioproducts and Biorefining. 2015;9(6):801-814.

15. Oilgae. The Comprehensive Oilgae Report. Oilgae, India. 2010.

16. Slade R, Bauen A. Micro-algae cultivation for biofuels: cost, energy balance, environmental impacts and future prospects. Biomass and Bioenergy. 2013;53:29-38.

17. Atlas, Ronald M. Handbook of Microbiological Media (4th edn), CRC press. 2010 .

18. Nichols HW, Bold HC. Trichosarcina polymorpha gen. et sp. nov. Journal of Phycology. 1965;1(1):34-38.

19. Rippka R, Deruelles J, Waterbury JB, et al. Generic assignments, strain histories and properties of pure cultures of cyanobacteria. Journal of General microbiology. 1979;111(1):1-61.

20. Crofcheck C, Shea A, Montross M, et al. Influence of media composition on the growth rate of Chlorella vulgaris and Scenedesmus acutus utilized for $\mathrm{CO} 2$ mitigation. Journal of Biochemical Technology. 2013;4(2):589-594.

21. Rudic V, Dudnicenco T. Process for cultivation of Green alga Haematococcus pluvialis (Flotow). MD Patent Nr. A. 2000;0154:2000.

22. Aiba S, Ogawa T. Assessment of growth yield of a blue-green alga, Spirulina platensis, in axenic and continuous culture. Journal of General Microbiology. 1977;102(1):179-182.

23. Schlösser UG. SAG-Sammlung von Algenkulturen at the University of Göttingen Catalogue of Strains 1994. Botanica Acta. 1994;107(3):113186. 
24. Guillard RR, Ryther JH. Studies of marine planktonic diatoms. i. Cyclotella nana hustedt, and detonula confervacea (cleve) gran. Canadian journal of microbiology. 1962;8:229-239.

25. Fogg GE. Growth and heterocyst production in Anabaena cylindrica Lemm: II. In relation to carbon and nitrogen metabolism. Annals of botany. 1949;13(3):241-259.

26. Fogg GE. The Blue-Green Algae. 1973.

27. Fogg G E, Thake B. Algal cultures and phytoplankton ecology. Univ of Wisconsin Press. 1975.

28. Guillard RR. Culture of phytoplankton for feeding marine invertebrates. Culture of marine invertebrate animals. 1975;pp.29-60.

29. Johnson MK, Johnson EJ, MacElroy RD, et al. Effects of salts on the halophilic alga Dunaliella viridis. Journal of Bacteriology. 1968;95(4):1461-1468.

30. Kwon B, Park N, Cho J. Effect of algae on fouling and efficiency of UF membranes. Desalination. 2005;179(1):203-214.

31. American Public Health Association. 10200 F. Phytoplankton Counting Techniques. Washington, DC, USA. 1995.

32. Liang F, Wen X, Geng Y, et al. Growth rate and biomass productivity of chlorella as affected by culture depth and cell density in an open circular photobioreactor. Journal of microbiology and biotechnology. 2013;23(4):539-544.

33. American Public Health Association, AW. Standard methods for the examination of water and wastewater. $\mathrm{NO}_{3}-$ spectrophotometric screening method. USA. 1998.

34. Bligh EG, Dyer WJ. A rapid method of total lipid extraction and purification. Canadian journal of biochemistry and physiology. 1959;37(8):911-917.

35. Lichtenthaler HK, Buschmann C. Chlorophylls and carotenoids: Measurement and characterization by UV-VIS spectroscopy. Current protocols in food analytical chemistry. 2001

36. Ilavarasi A, Mubarakali D, Praveenkumar R, et al. Optimization of various growth media to freshwater microalgae for biomass production. Biotechnology. 2011;10(6):540-545.

37. Wang W, Han F, Li Y, et al. Medium screening and optimization for photoautotrophic culture of Chlorella pyrenoidosa with high lipid productivity indoors and outdoors. Bioresource technology. 2014;170:395-403.
38. Bojović BM, Stojanović J. Chlorophyll and carotenoid content in wheat cultivars as a function of mineral nutrition. Archives of Biological Sciences. 2005;57(4):283-290.

39. Ikaran Z, Suárez-Alvarez S, Urreta I, et al. The effect of nitrogen limitation on the physiology and metabolism of Chlorella vulgaris var L3. Algal Research. 2015;10:134-144.

40. Juneja A, Ceballos RM, Murthy GS. Effects of environmental factors and nutrient availability on the biochemical composition of algae for biofuels production: a review. Energies. 2013;6(9):4607-4638.

41. Golub NB, Voyevoda DV. Effect of sulphur compounds on cultivation process of microalgae Chlorella vulgaris. 2013.

42. Harris G. Phytoplankton ecology: structure, function and fluctuation Springer Science \& Business Media. 2012.

43. Blair MF, Kokabian B, Gude VG. Light and growth medium effect on Chlorella vulgaris biomass production. Journal of Environmental Chemical Engineering. 2013;2(1):665-674.

44. Griffiths MJ, Harrison ST. Lipid productivity as a key characteristic for choosing algal species for biodiesel production. Journal of Applied Phycology. 2009;21(5):493-507.

45. Gossauer A, Engel N. Chlorophyll catabolism-structures, mechanisms, conversions.Journal of Photochemistry and Photobiology B: Biology. 1996;32(3):141-151.

46. Candan, Nilgün, Leman Tarhan. Changes in chlorophyll-carotenoid contents, antioxidant enzyme activities and lipid peroxidation levels in Zn-stressed Mentha pulegium. Turkish Journal of Chemistry. 2003;27:21-30.

47. Netto AT, Campostrini E, de Oliveira JG, et al. Photosynthetic pigments, nitrogen, chlorophyll a fluorescence and SPAD-502 readings in coffee leaves. Scientia Horticulturae. 2005;104(2):199-209.

48. Sharma KK, Schuhmann H, Schenk PM. High Lipid Induction in Microalgae for Biodiesel Production. Energies. 2012;5(5):1532-1553.

49. Widjaja A, Chien CC, Ju YH. Study of increasing lipid production from fresh water microalgae Chlorella vulgaris. Journal of the Taiwan Institute of Chemical Engineers. 2009;40(1):13-20.

50. Powell N, Shilton A, Chisti Y, et al. Towards a luxury uptake process via microalgae-defining the polyphosphate dynamics. Water research. 2009;14(17):4207-4213.

51. Sharma OP. Algae. 2011 